\title{
RNA干渉の若手研究者がつかんだノーベル医学生理学賞
}

\section{Youthful duo snags a swift Nobel for RNA control of genes}

\section{RNA による遺伝子発見抑制効果の発見からわずか 8 年でのスピード受賞。}

Nature Vol.443(488)/5 October 2006

Alison Abbott

今年のノーベル医学生理学賞を受賞し たのは、アンドルー・ファイヤーとク レイグ・メローの 2 人。ともに 40 歳 代の研究者だ。受賞理由となった発見 は、生物学研究を一変させた。そして 将来的には、病気の治療においても有 益なものとなる可能性を秘めている。

RNA 干渉 (RNAi)。これが彼らの発 見だった。遺伝子が発現する時、遺伝 子から細胞のタンパク質合成機構に指令 が送られる。その仲介を行うのは、その 遺伝子の構造と相補的な構造をもつメッ センジャーRNA（mRNA）だ。1998 年にNature に発表された画期的な論文 の中で、ファイヤーとメローらは、特 異的な二本鎖 RNA を使い、標的とした mRNA を破壊できることを実証した。

mRNA と相補的な配列を有する人工 RNA 分子を「アンチセンス」RNA と いうが、これを細胞に導入すると特定 の遺伝子の発現を抑制できることは、 その時点ですでに知られていた。しか し、その抑制効果はあまり大きくなく、 一貫性にも欠け、おまけに「センス」 RNA でも同じ効果がみられたことから、 論点がわかりにくくなっていた。

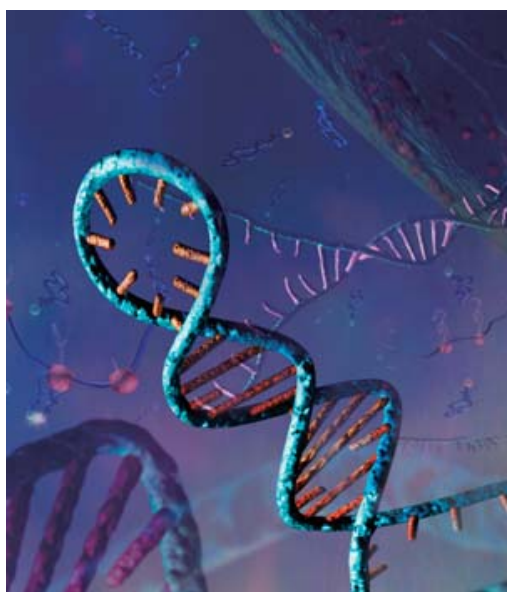

生物はRNAi によって、体内の遺伝子発現を 制御している。
ファイヤーとメローは、線虫の筋遺伝 子を使った一連の単純かつエレガントな 実験を行い、強力で一貫性のある遺伝 子発現抑制効果を得るためには、センス RNA とアンチセンス RNA が互いに結合 した二本鎖 RNA を使う必要があること を明らかにした。二本鎖 RNA を注入さ れた線虫は、まるで筋遺伝子の欠如した 変異型線虫のように、ぎごちなくぴくぴ くと動いた。また彼らは、mRNA は一 部の研究者がそれまで考えていたように 隠蔽されたわけではなく、二本鎖 RNA によって破壊されたことも明らかにし た。さらに、二本鎖 RNA はそれ自体の 複製を誘発し、細胞の間で広まり、子孫 にも受け継がれることを示した。

論文中で 2 人は、生物はこの機構 を使って体内の遺伝子発現を制御して いるのではないかという推論を示した が、まもなくその正当性は実証された。 RNAi は、ゲノムのいたるところで自 らを挿入して遺伝子の機能を阻害する 「ジャンピング遺伝子」を制御するため の重要な方法だったのだ。また、少な くとも単純な生物においては、RNAi が ウイルス感染の予防にも役立っている と考えられている。その後、RNAi 経路 については十分な解明が進み、これが すべての遺伝子、そして線虫だけでな く、ほとんどすべての生物種に当ては まることが明らかになった。

「研究対象である遺伝子の発現を抑制 する際にRNAi のツールを使わない研 究室はほとんどありません」。こう語る のは、2人の発見直後からRNAi 研究 の精鋭陣に加わったロックフェラー大 学のTom Tuschlだ。RNAi 試薬はこ れまでに、老化からがんまで、ありと あらゆるものに関与する遺伝子の同定 に使われてきた。臨床研究では現在、 RNAi を使って病気の原因遺伝子の活性 を低下させる方法が模索されている。
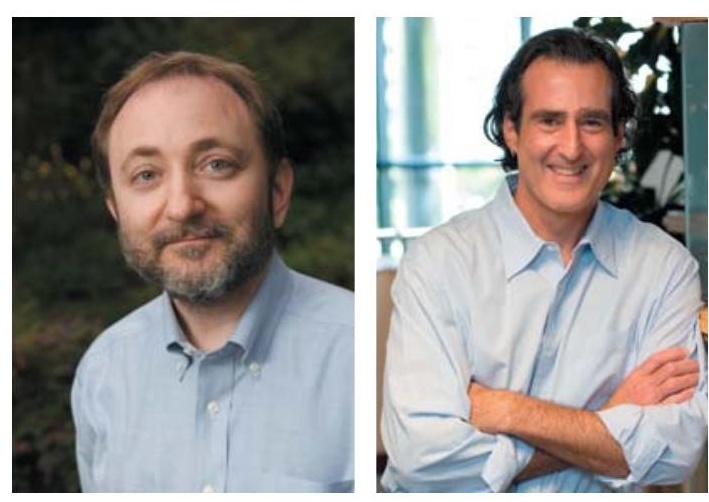

スタンフォード大学 (米) のアンドルー・ファイヤー 教授 (左、47 歳) とマサチューセッツ大学医学部 (米) のクレイグ・メロー教授 (右、45 歳)。

ノーベル賞は、受賞理由となる発見か ら長い年月を経て授与される場合がほ とんどだ。論文発表からわずか 8 年で の今回の受賞は、1993 年にノーベル化 学賞を受賞した Kary Mullis を思い起こ させる。このときは、彼が 1985 年に 発明したポリメラーゼ連鎖反応が受賞 理由だった。遺伝子を増幅させるこの方 法は、まさにRNAi 法と同じように急速 かつ広範に研究現場に普及した。

以前ファイヤーと一緒に研究した ことがあるユトレヒト大学の Ronald Plasterk は、彼がそのうちノーベル賞を 受賞することは確信していたものの、こ れほど早くだとは思っていなかったと語 る。今年の発表の朝、Plasterk は冗談 のつもりで、研究室のポスドクにファイ ヤーに電話してみろよ、なんて話をして いたという。「ところが彼が本当に受賞 したことがわかったので、ジョークは立 ち消えになってしまった」。

受賞の知らせを聞いてから間もなく 行われたインタビューで、メローは当 惑しているようすでコメントしていた。 「受賞するには若すぎるように思えま す。発見から受賞までが、異様に短く はないでしょうか」。 